\title{
The influence of water saturation on mechanical properties of ceramic bricks - tests on 19th- century and contemporary bricks
}

\author{
P. Matysek, T. Stryszewska $\bowtie$, S. Kańka, M. Witkowski \\ Cracow University of Technology, Faculty of Civil Engineering, Institute of Building Materials and Structures, (Cracow, Poland) \\ \tstryszewska@pk.edu.pl
}

Received 24 August 2015

Accepted 12 February 2016

Available on line 28 July 2016

\begin{abstract}
The paper presents test results concerning ceramic bricks produced in 1880's. Bricks were obtained from a building erected as part of Archduke Rudolf barracks in Krakow. The tests helped to specify changes in brick compressive strength and hardness, caused by water saturation in the ceramic material. For comparison purposes, tests were also carried out on contemporary bricks. Tests showed that mechanical properties of the ceramic bricks in the water saturation state were worse than in the dry state. The impact of strong brick moisture on changes of mechanical parameters is essential in terms of safety assessment for brick structures.
\end{abstract}

KEY WORDS: Brick; Mechanical properties; Compressive strength

Citation/Citar como: Matysek, P.; Stryszewska, T.; Kańka, S.; Witkowski, M. (2016) The influence of water saturation on mechanical properties of ceramic bricks - tests on 19th- century and contemporary bricks. Mater. Construcc. 66 [323], e095 http://dx.doi.org/10.3989/mc.2016.07315

RESUMEN: El impacto sobre las propiedades mecánicas de la saturación de agua de los ladrillos cerámicos contemporáneos y del siglo XIX. En el artículo se presentan los resultados del estudio de los ladrillos cerámicos producidos en los años 80 del siglo XIX. Los ladrillos se obtuvieron del edificio que forma parte de un conjunto de cuarteles del archiduque Rudolfo en Cracovia en Polonia. En los estudios se han determinado los cambios de la resistencia a la compresión y la dureza de los ladrillos, por efecto de la saturación de agua del material cerámico. A efectos comparativos, se han realizado también estudios de ladrillos producidos en la actualidad. Se ha comprobado que la saturación de agua de los ladrillos cerámicos lleva consigo una considerable disminución de las propiedades mecánicas. Por lo tanto, el impacto de la alta humedad de los ladrillos sobre el cambio de las propiedades mecánicas constituye un factor significativo en la evaluación de la seguridad en las construcciones de ladrillo.

PARABLAS CLAVE: Ladrillo; Propiedades mecánicas; Resistencia a la Compresión

Copyright: (C) 2016 CSIC. This is an open-access article distributed under the terms of the Creative Commons Attribution License (CC BY) Spain 3.0.

\section{INTRODUCTION}

Ceramic bricks were, and still are, one of the basic materials used to erect building structures. More often than not, brick walls are subject to strong moisture during use, and in exceptional circumstances, complete water saturation can be reached in masonry materials. So far, few experimental studies were carried out, concerning the impact of strong moisture of bricks, mortar and wall on their mechanical properties (1-4). These studies focused mainly on the search for dependencies between the degree of masonry material moisture and their durability. In (3), for fired ceramic bricks, coming from different historical periods, a decrease in compressive strength in the water saturation state 
was demonstrated, ranging from a few to over $20 \%$ compared to strength in air-dry state. Significantly lower compressive strength of bricks in the water saturation state has also been obtained in studies presented in $(1,2,4)$.

Depending on the raw material used, the method of forming and firing, ceramic bricks can have highly varied properties $(5-10)$. Ceramic bricks belong to a group of capillary-porous materials, which are characterized by open porosity from a few to several dozen percent $(11,12)$. The capillary-porous structure and phase composition of the ceramic body accelerate the formation of brick moisture as a result of capillary rise of water. In the brick material, along with water, dissolved salts are transported towards the external surfaces. Thus, after a long period with strong moisture, both water as well as the effect of crystallization of dissolved salts, such as sulphates or chlorides can impact physical-mechanical brick properties. An analysis of salt impact on ceramic properties is discussed in (13-16).

The purpose of the research presented in this paper was to determine the influence of ceramic brick saturation with clean, non-saline water on their mechanical properties. In literature, such tests are scarce. The most frequently tested aspect is the impact of moisture on brick compressive strength, without analyzing their phase or chemical composition.

The scope of our tests encompassed the following mechanical properties: compressive strength and surface hardness caused by the bloating of ceramics in time. In the tests, bricks from a building erected in the 1880's were used, as well as contemporary bricks. Both types of bricks were manufactured in Krakow within a time span of 120 years. The selected materials had a different phase composition, and internal structure, including pore structure. The historical bricks were taken from external walls of the building located on the ground floor level.

In the material tests, exposure conditions were assumed as both the short-term and long-term water saturation of ceramic bricks. The assumed processes for short- and long-term water saturation were supposed to simulate situations occurring periodically during floods and in structures exposed to permanent moisture.

\section{CHARACTERISTICS OF THE TESTED BRICKS IN A DRY STATE}

\subsection{Macroscopic and microscopic observations}

Two types of ceramic bricks were selected for tests, i.e. bricks produced in the 19th century (historical brick HB) and, as a comparative material, contemporary bricks (modern brick MB). Photos of exemplary HB and MB bricks along with their typical macrostructural images are shown in Figure 1.

The characteristic feature of historical bricks was their heterogeneity. In the HB bricks, there were areas with a good degree of homogenisation of fired components, as well as areas where one could see clear layers of non-homogenised raw materials. Moreover, in the HB bricks there were pores at a diameter of up to several $\mathrm{mm}$ and inclusions of non-comminuted components (mainly sand, grit and crushed brick debris), whose diameter ranged from 2 to $10 \mathrm{~mm}$.

MB material is characterised by far better raw material homogenization, and therefore a greater material uniformity in the entire brick volume. Generally, the inclusion grain diameter did not exceed $1 \mathrm{~mm}$.

Observations of the microstructure were carried out in a Zeiss EVO 10 scanning microscope, on the basis of a variable pressure secondary electron detection (VPSE) and back-scattered detection (BSD) in variable vacuum. Test samples were prepared in the form of fractures and polished sections. The observed surfaces were previously cleaned of silty particles without coated prior to test. SEM images of the tested materials are shown in Figures 2 and 3.

Microstructure observations showed that the morphology of aluminosilicates, the main component of each of the tested materials, was diverse. In MB material, minerals were more fine-crystalline compared to the minerals present in HB. It could be assumed that this was related to the initial
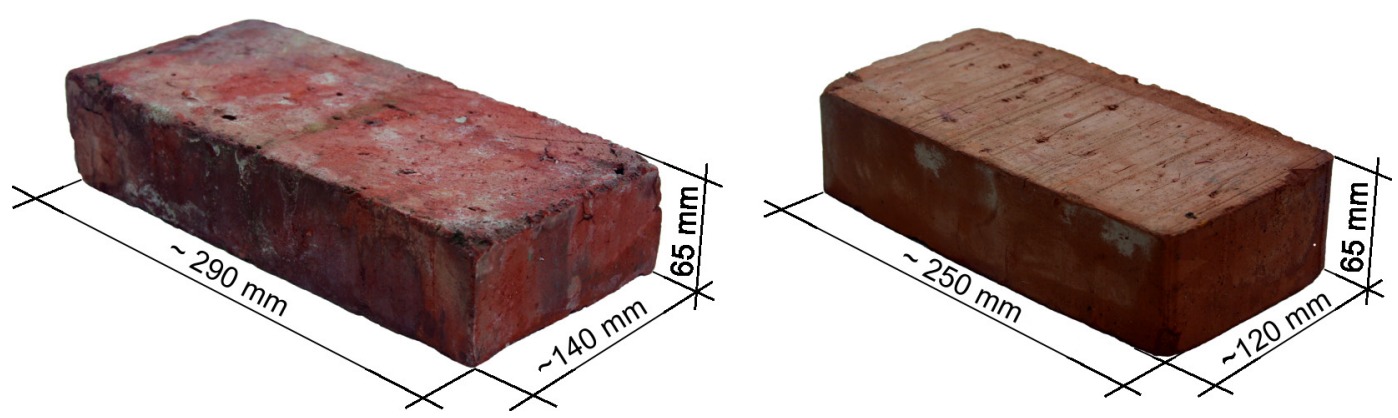

FIGURE 1. View of HB and MB tested bricks (from the left). 

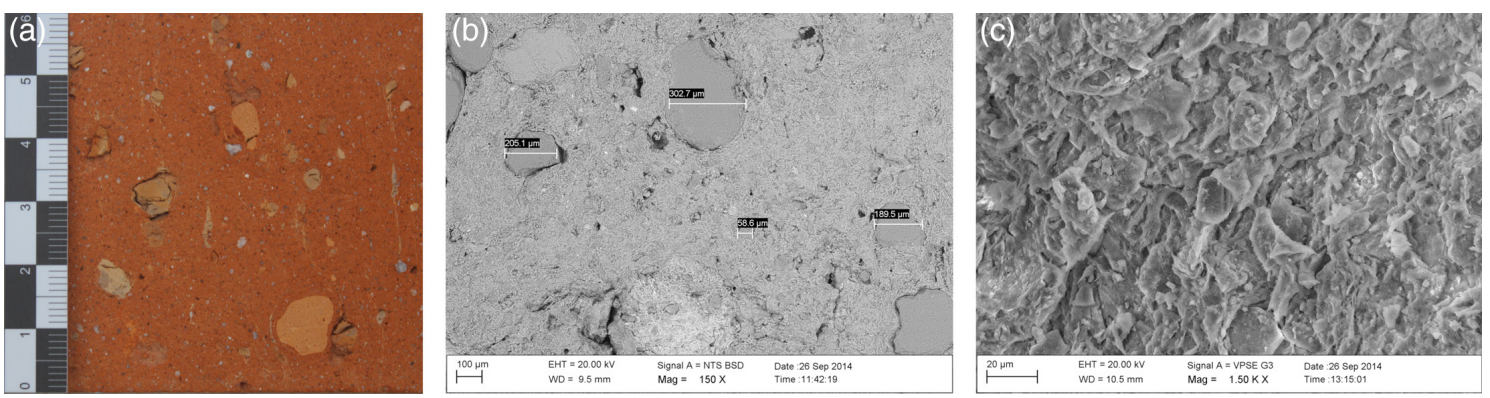

FIgURE 2. Macrostructural and microstructural of HB brick (from left) a) mag. $2 \times$ b) mag. $150 \times$ c) mag. $1500 \times$.
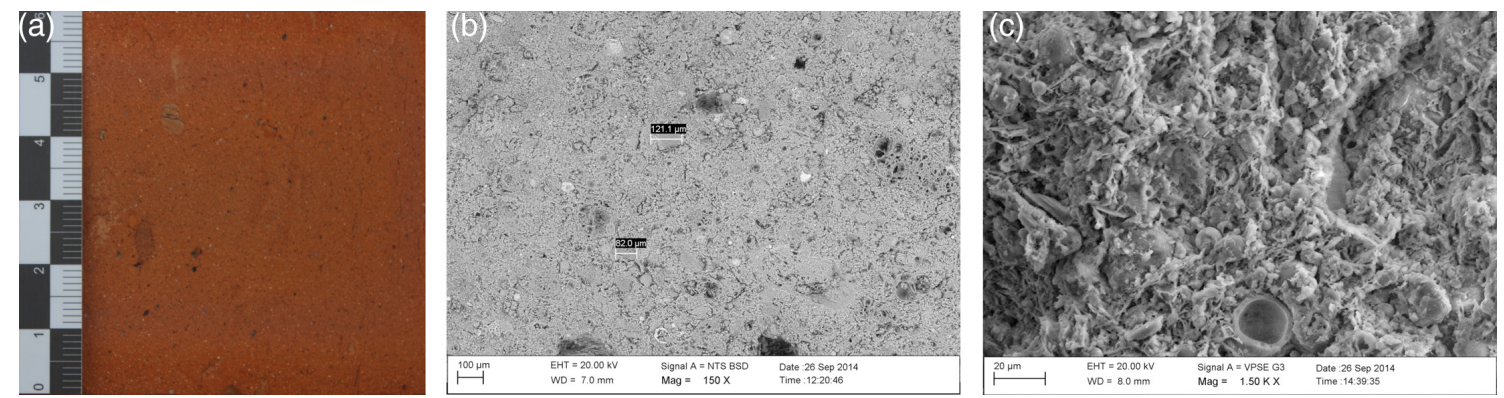

FIgURE 3. Macrostructural and microstructural of MB brick (from left) a) mag. $2 \times$ b) mag. $150 \times$ c) mag. $1500 \times$.

composition of raw materials and different production process (forming, and firing temperature and time). Bricks produced today often contain fly ash as a raw tempering material, instead of silica sand or comminuted brick rubble in their composition $(17,18)$. This addition is very fine-grained (often in the form of dust). Its presence causes the sealing of texture in contemporary ceramic bricks, and reduces the occurrence of larger inclusion grains coming from sand or rubble brick additions. The presence of fly ash was demonstrated by spherical forms identified in a SEM study of modern bricks (MB). The microscopic image of HB bricks, obtained with a $150 \times$ magnification, based on phase contrast, indicated the presence of quartz sand as filler (tempering material). Heterogeneity and discontinuity of ceramic material were present in the form of cracks.

\subsection{Phase composition}

Tests of phase composition were carried out respectively with diffractometric XRD in equipment Philips PW 1140. The analysis was conducted using support program X'Pert Highscore with data base PDF2. The results obtained are shown in Table 1.

The phase composition of both types of tested ceramic bricks was varied. On the basis of XRD analysis results it was found that the basic mineral present in HB material was quartz. This was the result of the application of sand or comminuted
TABlE 1. Phase composition of the tested materials

\begin{tabular}{|c|c|c|}
\hline \multirow[b]{2}{*}{ Phase } & Brick HB & Brick MB \\
\hline & \multicolumn{2}{|c|}{ Content of mass [\%] } \\
\hline Quarz & 70.3 & 35.9 \\
\hline Albite & - & 39.4 \\
\hline Microcline & 10.8 & - \\
\hline Mullite & - & 17.5 \\
\hline Anorthoclase & 16.5 & - \\
\hline Hematite & - & 6.1 \\
\hline Halloysite /mica & 2.4 & - \\
\hline Gypsum & - & 1.1 \\
\hline
\end{tabular}

brick debris as a tempering material. Other crystalline components are microcline and anorthoclase. Missing mullite demonstrated that the firing temperature was below $1000{ }^{\circ} \mathrm{C}$. With MB material, the dominant crystalline phase was albite, and later quartz and mullite. Lower quartz content compared to HB material is the result of different, tempering mineral additives in place of silica sand that are currently used. The presence of mullite in MB bricks may indicate a firing temperature above $1000{ }^{\circ} \mathrm{C}$, as well as the presence of fly ash, one of whose crystalline ingredients is mullite (18). In tests of the phase composition of both materials, the presence of unburnt clay minerals was not confirmed. 
It should be noted that XRD tests do not provide any information about the content of amorphous phases, present in both tested materials.

\subsection{Physical properties}

Selected physical properties of tested bricks are shown in Table 2.

The bulk density and skeleton density were respectively defined by the envelope density analyser method (GeoPyc 1360) and density analysis by a gas pycnometer (Quantachrome Ultrapyc 1200e). $\mathrm{HB}$ and $\mathrm{MB}$ brick skeleton densities were nearly the same. The tests, however, showed a difference in bulk density, which remains associated with the porosity of the ceramic structure. The materials were characterised by diverse total porosity, open, and especially closed one. The latter was discernibly higher in MB material, due to the presence of fly ash, in whose composition closed spherical particles can be found.

An absorption test was performed on $65 \times 65 \times 65 \mathrm{~mm}$ cuboidal samples, cut out of the bricks. Samples were saturated with water to reach a constant weight, in two ways: by means of capillary rise and soaking. The results showed that regardless of how water was put into the tested materials, the state of complete saturation was reached (19). HB material absorbability was discernibly lower than that of $\mathrm{MB}$.

TABLE 2. Physical properties of HB and MB bricks

\begin{tabular}{llrr}
\hline & & \multicolumn{2}{c}{ Brick } \\
\cline { 3 - 4 } Parameter & & \multicolumn{1}{c}{ HB } & \multicolumn{1}{c}{ MB } \\
\hline Bulk density & {$\left[\mathrm{g} / \mathrm{cm}^{3}\right]$} & 1.73 & 1.45 \\
Skeleton density & {$\left[\mathrm{g} / \mathrm{cm}^{3}\right]$} & 2.710 & 2.713 \\
Water absorption by weight & {$[\%]$} & 16.8 & 28.1 \\
Water absorption by volume & {$[\%]$} & 32.2 & 40.7 \\
Total porosity & {$[\%]$} & 36.2 & 46.5 \\
Open porosity & {$[\%]$} & 34.8 & 39.1 \\
Close porosity & {$[\%]$} & 1.4 & 7.4 \\
\hline
\end{tabular}

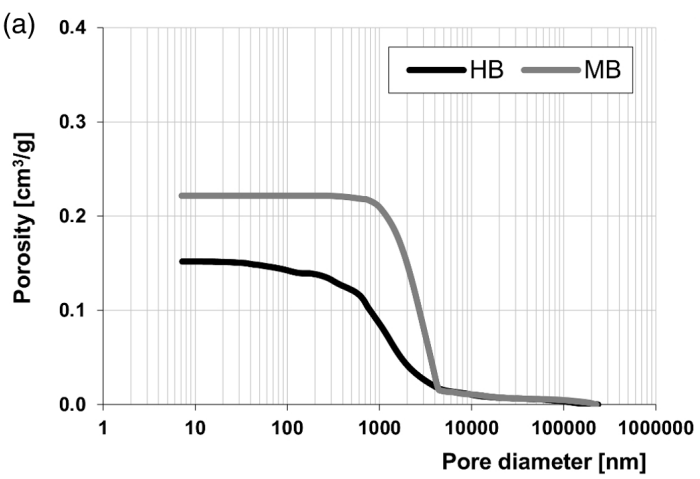

\subsection{Pore structure}

The pore structure was marked by mercury porosimetry, using a Quantachrome Poremaster porosimeter. In Figure 4 subsequent cumulative and population curves were shown. On this basis, depending on the diameter, categorization was made, concerning all open pores in $\mathrm{HB}$ and $\mathrm{MB}$ materials (Table 3).

MB ceramic material was characterized by poor pore size dispersion, when compared to HB material. In MB material, the dominant pore category were pores at diameters from 1000 to $4000 \mathrm{~nm}$, whose volume accounted for almost $75 \%$ of all the open pores. In HB material, the dominant category were pores at diameters from 200 to $2000 \mathrm{~nm}$, which in total accounted for almost $65 \%$ of all open pore. It should be noted, however, that in HB bricks, the share of the smallest and largest pores was significant and accounted for nearly $20 \%$ of the total volume of open pores.

TABle 3. Pore categorization in $\mathrm{HB}$ and MB ceramic bricks

\begin{tabular}{lcrcr}
\hline & \multicolumn{4}{c}{ Brick } \\
\cline { 2 - 5 } Category & \multicolumn{3}{c}{ HB } & \multicolumn{2}{c}{ MB } \\
\hline$[\mathrm{nm}]$ & $\mathrm{W}^{*}\left[\mathrm{~cm}^{3} / \mathrm{g}\right]$ & {$[\%]$} & $\mathrm{W}^{*}\left[\mathrm{~cm}^{3} / \mathrm{g}\right]$ & {$[\%]$} \\
$<200$ & 0.0136 & 9.0 & 0.0002 & 0.0 \\
$200-1000$ & 0.0543 & 35.8 & 0.0125 & 5.6 \\
$1000-2000$ & 0.0433 & 28.5 & 0.0653 & 29.5 \\
$2000-3000$ & 0.0157 & 10.3 & 0.0671 & 30.3 \\
$3000-4000$ & 0.0058 & 3.8 & 0.0516 & 23.2 \\
$4000-5000$ & 0.0039 & 2.6 & 0.0112 & 5.1 \\
$>5000$ & 0.0152 & 10.0 & 0.0139 & 6.3 \\
$\mathrm{~V}_{\text {pores }} * *$ & 0.1518 & 100.0 & 0.2216 & 100 \\
\hline
\end{tabular}

* $\mathrm{W}$ - volume contribution of pores determined based on pore distribution curves of population

$* * \mathrm{~V}_{\text {pores }}$ - total pore volume

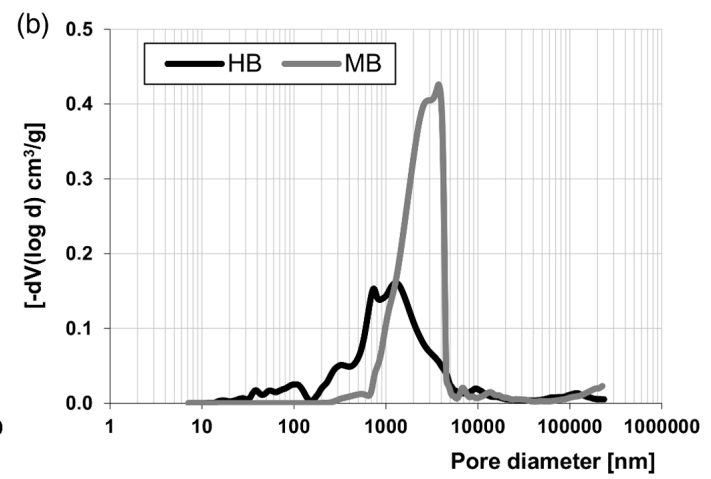

FIgURE 4. Cumulative (a) and population (b) curves of ceramic material porosity in HB and MB bricks. 


\section{TEST METHODOLOGY OF BRICK SATURATED IN WATER}

\subsection{Testing compression strength and hardness}

For tests, $12 \mathrm{HB}$ and $12 \mathrm{MB}$ bricks were selected randomly. Support surfaces of each brick were polished in order to obtain parallel planes. Then, from each brick, cubes were cut out, with sides equal to the brick height. Out of one contemporary brick, it was possible to cut 3 samples, whereas from one historical brick -6 cuboidal samples could be obtained. Designation of compressive strength and hardness was carried out for HB and MB materials in the dry state, in a short-term water saturation state (1 month), and in a state of prolonged water saturation (6 months). Tests were carried out on series consisting of 18 samples for $\mathrm{HB}$, and 9 samples for MB material.

Tests of brick compressive strength were carried out in Zwick 1200 testing machine. The load velocity was comply with EN 772-1 (20). The load direction each time was perpendicular to the support surfaces.

Brick hardness tests were carried out in Z100 Zwick testing machine, equipped with a penetrator with a ball at a diameter of $5 \mathrm{~mm}$. The penetrator was inserted into tested materials at a constant speed of $1 \mathrm{~mm} / \mathrm{min}$ to a depth of $1 \mathrm{~mm}$. After the insertion of the penetrator, force was stabilised for $5 \mathrm{sec}$ and its maximum value was recorded, which was then adopted as the hardness measure (21).

\subsection{Spectroscopic tests}

The MIR measurements were performed using the Bruker Optics-Vertex 70V spectrometer. The samples were prepared using the tablet method in $\mathrm{KBr}$. The absorption spectra were recorded in 128 scans at a resolution of $4 \mathrm{~cm}^{-1}$. The measurement was carried out for dry samples and after long-term water saturation.

\subsection{Electrolytic conductivity of aqueous solutions tests}

Aqueous solutions resulting from longterm immersion of bricks in water were tested. Conductivity tests of these solutions have been carried out. The results were compared with the conductivity of distilled water. Electrolytic conductivity competent by means of a WTW 3430 equipped with a sensor TetraCon 925 of the cell constant $k=0.475$ was determined.

\section{TEST RESULTS AND DISCUSSION}

\subsection{Brick compression strength and hardness}

The test purpose was to determine the influence of water in ceramic texture on compressive strength and hardness of bricks. On the basis of the results of compressive strength and hardness tests carried out on bricks treated with water, the impact of soaking time on mechanical properties was evaluated for periods of 1 and 6 months.

Compressive strength of each sample was calculated as the ratio of destructive force against the area of its cross section. As a measure of brick hardness, the force necessary for the penetrator insertion into the material to a depth of $1 \mathrm{~mm}$ was assumed. The results of a statistical analysis of the results of strength and hardness tests carried out on the bricks were shown in Tables 4 and 5.

In order to assess the impact of water on mechanical properties of ceramic bricks, compressive strength $\left(\eta_{\mathrm{f}}\right)$ and hardness $\left(\eta_{\mathrm{h}}\right)$ reduction coefficients were introduced, defined as relationship between the value of this feature defined after short-term or long-term treatment in water and the value of a specific feature in the dry state. The calculated reduction coefficients were shown in Table 6 .

Table 4. Brick compressive strength depending on their moisture condition

\begin{tabular}{llcc}
\hline & & Brick \\
\cline { 2 - 3 } Condition of the tested material & Properties/descriptive statistics & HB & MB \\
\hline Dry (dried to constant mass) & Compression strength [MPa] & 22.9 & 35.0 \\
& Number of samples & 18 & 9 \\
& Standard deviation [MPa] & 6.6 & 4.5 \\
Short-term water saturation & Coefficient of variation [\%] & 28.9 & 12.9 \\
(water treatment for one month) & Compression strength [MPa] & 20.7 & 31.9 \\
& Number of samples & 18 & 9 \\
Long-term water saturation & Standard deviation [MPa] & 7.0 & 5.7 \\
(water treatment & Coefficient of variation [\%] & 33.9 & 17.9 \\
for six months) & Number of samples & 20.3 & 27.5 \\
& Standard deviation [MPa] & 18 & 9 \\
& Coefficient of variation [\%] & 6.5 & 4.1 \\
\hline
\end{tabular}


TABLE 5. Brick hardness depending on their moisture condition

\begin{tabular}{llrc}
\hline & & Brick \\
\cline { 2 - 3 } Condition of the tested material & Properties/descriptive statistics & HB & MB \\
\hline Dry (dried to constant mass) & Hardness [N] & 2324 & 2057 \\
& Number of samples & 18 & 9 \\
& Standard deviation [MPa] & 500 & 373 \\
Short-term water saturation & Coefficient of variation [\%] & 21.5 & 18.1 \\
(water treatment for one month) & Hardness [N] & 1998 & 1749 \\
& Number of samples & 18 & 9 \\
Long-term water saturation & Coefficient of variation [\%] & 436 & 338 \\
(water treatment for six months) & Hardness [N] & 21.8 & 19.3 \\
& Number of samples & 1918 & 1409 \\
& Standard deviation [MPa] & 18 & 9 \\
\end{tabular}

TABLE 6. Brick compressive strength $\left(\eta_{\mathrm{f}}\right)$ and hardness $\left(\eta_{\mathrm{h}}\right)$ reduction coefficients

\begin{tabular}{llll}
\hline & & \multicolumn{2}{c}{ Brick } \\
\cline { 3 - 4 } Parameter & Condition of the tested material & HB & MB \\
\hline$\eta_{\mathrm{f}}$ & $\begin{array}{l}\text { Short-term water saturation } \\
\text { (water treatment for one month) }\end{array}$ & 0.90 & 0.91 \\
& $\begin{array}{l}\text { Long-term water saturation } \\
\text { (water treatment for six months) }\end{array}$ & 0.89 & 0.79 \\
$\eta_{\mathrm{h}}$ & $\begin{array}{l}\text { Short-term water saturation } \\
\text { (water treatment for one month) }\end{array}$ & 0.86 & 0.85 \\
& $\begin{array}{l}\text { Long-term water saturation } \\
\text { (water treatment for six months) }\end{array}$ & 0.83 & 0.68 \\
\hline
\end{tabular}

\subsection{The structure of brick in the light of middle infrared spectroscopy}

Measurements were performed for dry and after long-term water saturation of bricks MB and HB. The results are given in Figure 5. The goal of this test was to find differences between chemical bond in tested materials before and after saturation.

Based on the results of research it was found that in material MB was more amorphous phase than in the material HB. This follows from the comparison of the full width at half maximum main band which is bigger for MB material.

In MB material the disappearance of the characteristic bands at 3547, 3409, 1685 and $671 \mathrm{~cm}^{-1}$ were observed. These bands were characteristic of gypsum. Thus, in the dry sample there was gypsum but in wet sample it was absent. During the soaking process the gypsum was dissolved.

The research showed that after soaking in MB material a new band at $962 \mathrm{~cm}^{-1}$ wad appeared. This band is associated with broken silicon-oxygen $\left(\mathrm{Si}-\mathrm{O}^{-}\right)$bridges $(22,23)$. This means that the water saturation caused degradation of silicon-oxygen network breaking of silicon-oxygen bridges Si-O-Si $(22,23)$. In HB material the changes were not observed.

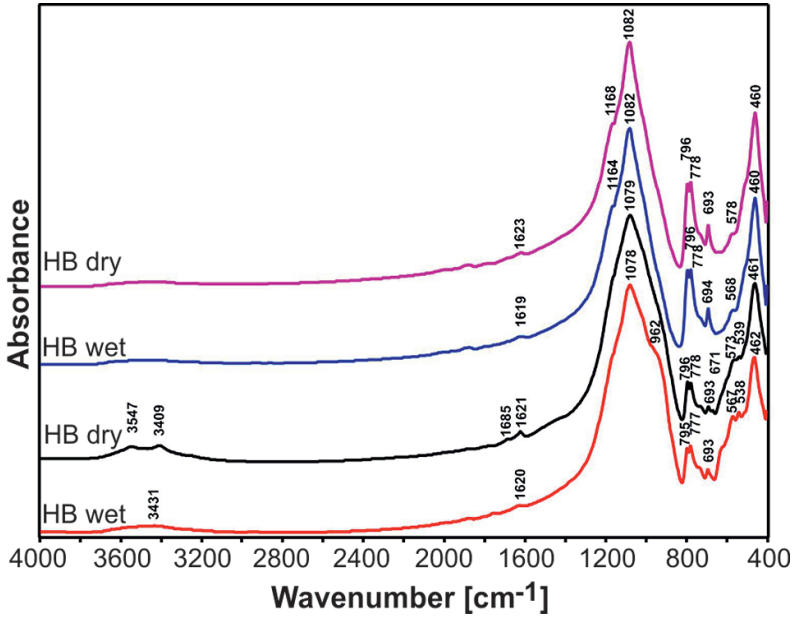

FIgURE 5. MIR spectra of $\mathrm{HB}$ and MB materials in dry state and after long-term water saturation state.

\subsection{Electrolytic conductivity of aqueous solutions remaining after soaking the bricks}

Electrolytic conductivity of aqueous solutions depends on the presence within them of cations and anions. For comparison, electrolytic conductivity of distilled water is about several $\mu \mathrm{S}$. Based on the results of measured conductivity and of the relevant rate constants can be dissolved content of substances in the water, and this case, the amount of ions that passed into solution from tested materials. Electrolytic conductivity of solutions after longterm water saturation of materials $\mathrm{HB}$ and $\mathrm{MB}$ were $675 \mu \mathrm{S}$ and $1290 \mu \mathrm{S}$ respectively. On this basis the contents of leached material from the HB and MB were calculated. The amounts of leached material were respectively $0.4 \%$ and $0.9 \%$ by weight. From bricks MB leached more than two times more ions than from bricks HB. This process caused a rise in micro-voids, the presence of which has weakened the ceramic material. 


\subsection{Discussion of results}

Compressive strength of ceramic bricks depends on many factors that characterize their internal structure. These factors comprise, inter alia: uniformity of component distribution in the ceramic material, pore structure (density), the presence of inclusions, scratches (technological cracks) and micro-defects in the vitreous phase structure $(18,24)$. The ceramic texture is determined by the type of raw materials used, and the brick production method (forming, seasoning before firing, firing technology) (7-10, 25).

In our own tests, bricks that differed strongly in their microstructure, chemical and phase composition, and pore structure were used. Historical bricks were taken from the external walls of the building erected around 1880's. HB bricks were exposed to external environmental factors and loads for a long time. In contrast to the HB bricks, MB bricks were not subject to environmental impacts and loads before testing.

The tests showed that mechanical properties of both brick types in the water saturation state were worse than in the dry state. The tests showed also that regardless of the type of tested bricks, when short-term water saturation took place, the decrease in compressive strength was about $10 \%$.

Long-term saturation of $\mathrm{HB}$ material did not result in significant decreases in strength. On the other hand, it was observed that in the case of MB material, saturated with water over a period of 6 months, the strength in the water saturation state in relation to the strength marked on dried material was $21 \%$ lower. The reason for this can be justified by the high content of volatile ashes in MB material. The high share of this type of tempering component changed the texture of ceramic bricks. Fly ash, depending on their type, has an initial sintering temperature of between $880^{\circ} \mathrm{C}$ and $960^{\circ} \mathrm{C}$ (26). This means that some types of fly ashes in ceramic bricks may not sinter and act as a filler. Spectroscopic studies showed that after long-term saturation in material MB processes leaching gypsum and breaking silicon-oxygen bridges occurred. For each brick type the process of leaching of ions from the ceramic structure was also noted. Both these processes resulted in weakening the ceramic materials. Decrease of the strength was also apparent from the reduction of friction between the structural elements of the saturated materials subjected to compression. The water in material acts as a lubricant for moving elements of the adjacent sides of the smaller or larger cracks occurring in the structure of bricks (cracks in the ceramic material are shown in Figure 2, 3). This phenomenon by Neville for capillary-porous materials was described (27).

The hardness of the two tested brick types in the dry state differed by $13 \%$. Greater surface hardness was demonstrated by HB material, which in fact had less strength but at the same time, a definitely lower porosity. Comparable drops in hardness for samples tested in the water saturation state by shortterm treatment in water were obtained for $\mathrm{HB}$ and MB bricks - respectively $14 \%$ and $15 \%$. Along with the increased water saturation time, a greater hardness drop was observed (for MB material by about $30 \%$ ). Decreases in the hardness of materials in the water saturation state were bigger than decreases in the compressive strength of bricks. This can be explained by the fact that hardness test took place on the surface of brick samples where the intensity of the change processes of ceramic structures (caused by water) was the highest.

\section{CONCLUSION}

The paper presents test results concerning two types of fired ceramic bricks, strongly different with respect to their physical-chemical properties. Tests were carried out on historical (produced in the 1880 's) and modern bricks. Due to different technological processes and materials used, the bricks were significantly different with respect to their phase composition and pore structure.

The compressive strength of the tested bricks in the water saturation state was much lower than in the dried sate. Time of soaking in water of bricks affected the results. The decrease in the compressive strength of bricks tested after soaking in water for six months was greater than bricks tested after soaking of 1 month. The largest decrease $(21 \%)$ for contemporary bricks (material MB) was obtained.

It has been shown that decreases in the compressive strength of the brick tested in the water saturation state were associated with changes to the structure of ceramics that occurred under the influence of water. The lower compressive strength of bricks on the water saturation state was due also to the lower friction between the structural elements of ceramics separate cracks (and micro-cracks) seen in the materials.

Decrease in hardness of brick saturated with water compared to dry bricks was larger than the decrease in the compressive strength of bricks tested in the wet and dry state. This effect was due to the fact that the processes related to occur under the influence of water were most intense on the surface of samples, where the contact of the ceramic material with water was the greatest. The largest decrease in hardness $(32 \%)$ for tested contemporary bricks after long-term soaking in water was obtained.

Strong moisture of bricks (nearly complete saturation with water) and their lower strength, which may occur in practice, affect the reduction in masonry strength. Lower compressive strength of bricks in the water saturation state compared to the strength of dry bricks, registered in tests as 
ranging from 10 to $21 \%$ and should not be neglected in the assessment of carrying capacity and durability of the structure. Strong brick moisture caused by water affects the reduction of their hardness, which should be taken into account in the analysis of nondestructive test results, based on material hardness measurements.

\section{ACKNOWLEDGEMENT}

The paper is the result of projects no. L1/234/ DS/2012 and L1/339/DS/2014 which were conducted in Institute of Building Materials and Structures, Faculty of Civil Engineering, Cracow University of Technology.

\section{REFERENCES}

1. Foraboschi, P.; Vanin, A. (2014) Experimental investigation on bricks from historical Venetian buildings subjected to moisture and salt crystallization. Eng Fail Anal. 45, 185-203. http://dx.doi.org/10.1016/j.engfailanal.2014.06.019.

2. Witzany, J.; Cejka, T.; Zigler, R. (2010) The effect of moisture on significant mechanical characteristics of masonry. Eng Struct Technol. 2, 79-85.

3. Matysek, P.; Witkowski, M. (2013) The assessment of humidity impact on the strength of brick masonry. Build Mater. 5, 10-12 [in Polish].

4. Amade A.M.; Martin J.V.; Colville, J. (2004). The effect of moisture on compressive strength and modulus of brick masonry. Proc. 13th International Brick and Block Masonry Conference. Amsterdam.

5. Cultrone, G.; Sebastián, E.; de la Torre, M.J. (2005) Mineralogical and physical behaviour of solid bricks with additives. Constr Build Mater. 19, 39-48. http://dx.doi. org/10.1016/j.conbuildmat.2004.04.035.

6. Elert, K.; Cultrone, G.; Navarro, C.R.; Pardo, E.S. (2003) Durability of bricks used in the conservation of historic buildings - influence of composition and microstructure. $J$ Cult Herit. 4, 91-96.

7. Cultrone, G.; Sebastian, E.; Elert, K.; de la Torre, M.J.; Cazallo, O.; Navarro, C.R. (2004) Influence of mineralogy and firing temperature on the porosity of bricks. $J$ Eur Ceram Soc. 24, 547-564. http://dx.doi.org/10.1016/ S0955-2219(03)00249-8.

8. Fernandes, F.M.; Lourenco, P.B.; Castro, F. (2010) Ancient clay bricks: manufacture and properties. In: Bostenaru Dan M; Přikryl R; Török Á. Materials, Technologies and Practice. Historic Heritage Structures, Springer, (2010).

9. Egermann, R.; Mayer, K. (1988) Die Entwicklung der Ziegelherstellung und ihr Einfluss auf die mechanischen Eigenschaften von Mauerziegeln. In: Erhalten historisch bedeutsamer Bauwerke - Baugefüge, Konstruktionen, Werkstoffe, Sonderforschungsbereich 315, Universität Karlsruhe, Ernst und Sohn, Berlin, (1988).
10. Franke, L.; Schumann, I. (1998) A brief history of brickmaking in Northern Germany. In: Bear NS, Livingston RA, Fitz S. Conservation of Historic Brick Structures, United Kingdom: Donhead Publishing Ltd.

11. Nadachowski, F.; Jonas, S.; Wodnicka, K. (2003) Outline of Ceramography. Ceramics 82. PAN in Cracow and Polish Ceramic Society, Cracow (2003). [in Polish]

12. Hamilton, A.; Hall, C.; Pel, L. (2008) Sodium sulfate heptahydrate: direct observation of crystallization in a porous material. J Phys D Appl Phys. 41, (212002), 1-5.

13. Stryszewska, T. (2014) The change in selected properties of ceramic materials obtained from ceramic brick treated by the sulphate and chloride ions. Constr Build Mater. 66, 268-274. http://dx.doi.org/10.1016/j. conbuildmat.2014.05.066.

14. Benavente, D.; Linares-Fernandez, L.; Cultrone, G., Sebastian, E. (2006) Influence of microstructure on the resistance to salt crystallization damage in brick. Mater Struct. 39, 100-113.

15. Larsen, E.S.; Nielsen, C.B. (1990) Decay of bricks due to salt. Mater Struct. 23, 16-25.

16. Lubelli, B.; van Hees, R.; Grootb, J.W.P. (2004) The role of sea salts in the occurrence of different damage mechanisms and decay patterns on brick masonry. Constr Build Mater. 18, 119-124. http://dx.doi.org/10.1016/j. conbuildmat.2003.08.017.

17. Monteiro, S.N.; Vieira, C.M.F. (2014) On the production of fired clay bricks from waste materials: A critical update. Constr Build Mater. 68, 599-610.

18. Cultrone, G.; Sebastián, E. (2009) Fly ash addition in clayey materials to improve the quality of solid bricks. Constr Build Mater. 23, 1178-1184. http://dx.doi.org/10.1016/j. conbuildmat 2008.07.001.

19. Stryszewska, T. (2014) The influence of full water saturation on selected physico-mechanical properties of ceramic bodies. Ceram Mater. 66 [1], 81-87 [in Polish].

20. EN 772-1. Methods of tests for masonry units - determination of compressive strength. 2001.

21. Stryszewska, T. (2012) Selection of the diagnostic features of the studies the impact of water-soluble salts on the durability of ordinary bricks. Build Mater. 5, 69-71 [in Polish].

22. Sitarz, M. (2011) The structure of simple silicate glasses in the light of Middle Infrared spectroscopy studies. $J$. Non-Crystalline Solids 357, 1603-1608. http://dx.doi. org/10.1016/j.jnoncrysol.2011.01.007.

23. Mozgawa, W.; Sitarz, M.; Rokita, M. (1999) Spectroscopic studies of different aluminosilicate structures. J. Molecular Structure 251, 511-512.

24. Awgustinik, A.J. (1980) Ceramic. Arkady, Warsaw, (1980). [in Polish].

25. Nadachowski, F.; Jonas, S.; Ptak, W. (2012) Introduction to technological design in ceramics. AGH; Cracow, (2012). [in Polish].

26. Małolepszy, J.; Wons, W. (2007 June) Influence of physicchemical properties of coal fly ash on construction ceramic products, In: Proceedings of Conference Matbud, Cracow, Poland; 340-348 [in Polish].

27. Neville, A.M. (1973) Properties of concrete. London: Pitman Publishing (1973). 